\title{
A pedagogic approach by contextual immersion
}

\author{
Samuel Ismael Billong IV, Bernabé Batchakui, René Simo Nono, Georges Kouamou
}

Department of computer Engineering, National Advanced School of Engineering University of Yaoundé I Cameroun, Cameroon.

\begin{abstract}
In several training institutions in sub-Saharan Africa today, the competencybased approach to teaching (CBA) has been adopted at the secondary school level. In Cameroon, based on our experience in teaching, we have found that this approach does not suit all categories of learners, generally the youngest. With the advent of Information and Communication Technologies (ICT), learners spend most of their time on ICT's gadgets (mobile phone, tablet, etc ...). In this paper, we propose a complement to the CBA approach through pedagogic differentiation. This differentiation takes into account the learner's environment and adds a playful and captivating aspect to the techno-pedagogic tools to be made available to them through the gadgets they use. We call this approach contextual immersion. It starts from real life situation familiar to the learner. The tool made available to the learner, which integrates this approach, guides him/her progressively towards the solution to the problem posed and a generalization that summarizes the course that will be transmitted.
\end{abstract}

Keywords: contextual immersion; pedagogical differentiation; captivating ;playful; competency-based approach; techno-pedagogical tools. 


\section{Introduction}

Cameroon has adopted recently as teaching method, the CBA - ELS / EA (competencybased approach with entry by life situations / entry by activities) in which, the student is supposed to be at the center of learning. Based on our experience, we have noticed that students at the secondary level are more interested in games and very often do not find the lessons attractive, captivating or even having some fun. Also, they turn to look for shortcuts that may require less effort or time.

We carried out a survey on the importance of an approach linked to daily life and ICT tools through techno-pedagogy on a sample of 344 students in the $5^{\text {th }}$ and $6^{\text {th }}$ forms in literary classes. The outcome was that the CBA course was not captivating, but rather restrictive. Indeed, the activities outlined in the approach were not illustrative and contextual. On the other hand, with illustrations in the form of a series that we propose to the students, they would be captivated and available for learning in addition to the playful aspect that these would introduce. The challenge in the following is therefore to build a pedagogy that takes into account the current evolution of technology and learners' opinions.

A question that immediately follows is what kind of pedagogic approach, which at the same time takes into account the desired objective while integrating a playful aspect related to the electronic objects cherished by the learners can be implemented? It is clear that if the learner had the choice or an opinion on the teaching methods to be used for his lesson, we will have future men and women ready to live in harmony with their environment, highlighting their different talents. It is well known that one of the learning objectives is to promote the mastery of our environment. Based on these, we thought to bring added value to the CBA by accompaning learners who are immersed in their context, come out with the solution to a problem, and the general formulation of this type of problem. At the end, learners develop techniques of practical use of the acquired skill while having fun and saving time.

The rest of the document is elaborated as follows: In section 2 we present a background check on the most recent approaches. In section 3, we present our proposed approach and its experimentation. Section 4 and 5 are respectively reserved for discussions and a general conclusion.

\section{Background check}

The result of learning is usually not instantaneous. Learning is a long-term skill with well adapted approaches that can be extended or transferred to different contents or situations. A pedagogic objective consists in well orienting what is expected from the learner at the end of the teaching-learning process. This process requires the ability to transfer and to develop 
the steps that lead to the desired competency. The two approaches most commonly used in Cameroon's education system are the objective-based approach (OBA) and the competency-based approach (CBA), which we present below.

\subsection{Objectiive-based approach}

According to Nguyen and Blais (2007), OBA, which stems from the increase in knowledge and clientele, consists of planning teaching activities that include needs analysis, goal setting and the choice of teaching strategies and evaluation.

Objectives state what is to be learned, represent what is expected of students, and express what the teacher values for the learners and the level of cognitive ability expected of learners. Thus, these objectives direct the way in which the learner can accomplish a certain self-assessment following the example of his teachers, develop the ability to set goals for himself that serve him during his lifelong self-study (Carrette and Rey, 2010). Education is organized and promotes a convergence of efforts towards the achievement of these objectives. This approach has been studied by several researchers as Nguyen and Blais (2007), Bloom et al. (1975), Bonner (1999), De Landsheere and de Landsheere (1989), and Fontaine (1989). Some limitations of the approach are:

$>$ the non-operationalization of the objectives in terms of practical know-how;

$>$ the failure to take into account the orientation of the learner towards activities for which he is naturally gifted (the objectives are the same for all at each level: no pedagogic differentiation);

$>$ the learner, for whom the others decide on the objectives, is compressed in knowledge;

$>$ Teacher-Learner communication is verticality downwards. The large volume of notes to be taken makes studying or revision tedious, which, according to the learner, is comparable to a chore;

$>$ the absence of playful aspects that match the age of learners in the learning process does not always make learning captivating.

\subsection{Competency-based approach}

In the CBA, learning aims at resolving complex situations, and it is advisable to place the learner at the center as early as possible, while providing appropriate support which will gradually lead him or her to act independently. This approach has been studied in several forms by certain researchers, for example, Bosman et al. (2000), Boutin \& Julien (2000), Roegiers (2001), Burns \& Klingstedt (1973), and Burke (1989). The CBA is limited in that:

$>$ the assumed skills of the learner are not always acquired due to the lack of interest of learners;

$>$ mismatch between the time available and the volume of material to learn; 
not always suitable for the under-18 age group because they do not feel compelled to be productive;

$>$ like OBA, it lacks the playfulness aspect.

Given the limitations of these two approaches, a more optimal approach would bring the learner to solve problems in his context, leading to course notes reduction and time gain. To get close to that, we intend to bring in ICT tools which makes learning captivating, easier and more objectively oriented towards exposing natural talents. This approach, which we henceforth call "Contextual Immersion Pedagogy", will be implemented in a technopedagogic environment with the application of pedagogic differentiation as indicated by the following authors: Avanzini (1986), Baluteau (2014), Burns (1971) and Cèbe et al. (2015).

\section{Contextual Immersion Pedagogy: Experimentation}

Our contribution in the design of this new pedagogic approach will focus on the Cameroonian context. the process is led by the following scheme.

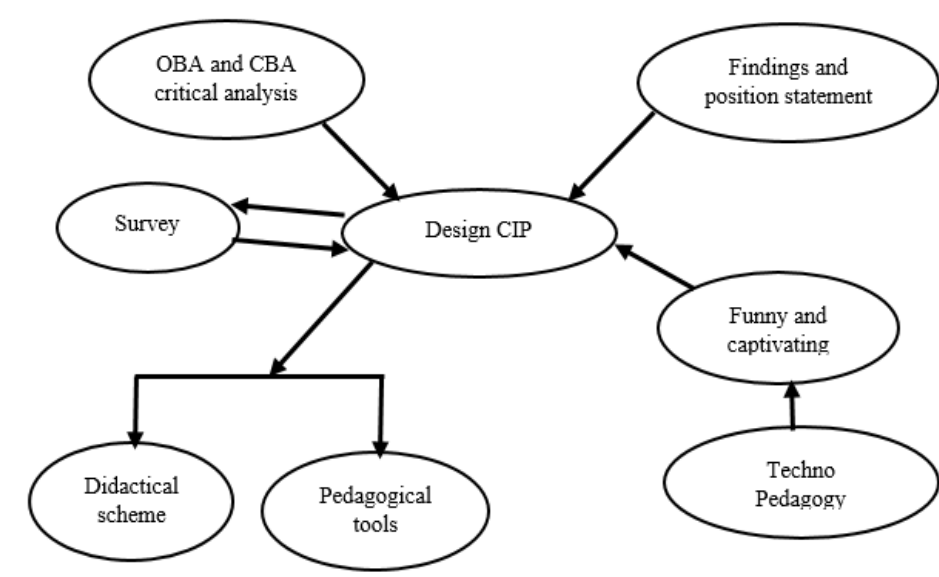

$\mathrm{OBA}=$ objective based approach $\mathrm{CBA}=$ competence based approach; $\mathrm{CPI}=$ contextual immersion approach

Figure 1. The design process.

\subsection{Development of the new Contextual Immersion Pedagogy approach}

a) Scripting of the course by the teacher (preparation of a lesson)

- Create a didactic situation where, using the lesson to be taught, learners find solutions to their daily problems by bringing in the playful aspect to better captivate them. 
- Make a pedagogic differentiation that will take into account different categories of learners.

- Write the lesson in the form of the script of a series to make it available for video editing.

- Make sure that the video that will be edited for a lesson be short (about ten minutes).

b) Learning situation

- Install techno-pedagogic material beforehand.

- Project the video of the didactic situation for the lesson.

- Take 15 minutes for feedback from learners based on the projected situation.

- Conclude in 25 minutes with a brief summary of the lesson.

- Direct students to the bibliography.

- Make the video available to them after the lesson.

\subsection{Experiences and results}

a) Description of the experimental setting

The experimental environment we chose for this new approach is the $6^{\text {th }}$ form in the ODZA Adventist School Complex in Yaoundé, Cameroon, during the 2019-2020 school year. A lesson was delivered in this class of 71 students following the steps in Section 3.1. In order to measure the impact of this approach, we chose a subject that the students of this class do not generally like, "Mathematics". A lesson on simple linear equations with one unknown was delivered according to the setting below:

1) Equipment used:

- a laptop computer;

- small speakers connected to the computer;

- a video projector;

- a projection plane tool;

- a CD containing the video of the immersion situation.

2) Teaching situation:

- We played the video for 12 minutes in the classroom with all the students.

- A course summary was made with the students after the contextual immersion in 30 minutes.

- Then we administered a questionnaire to have their opinions about this way of approaching a lesson.

b) Results on the two surveys

i) Survey on the importance of the approach based on techno-pedagogy in secondary education 
The graphical representations below give us the trend of learners' opinions.

Would you like to improve your academic skills using ICT tools?

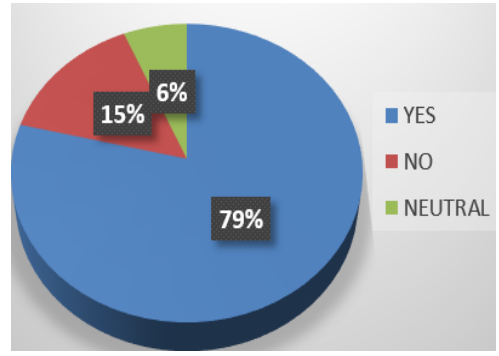

Figure 3. courses with ICT tools.
If your lesson was in the form of a television series (captivating with practical work and simulation example) where each chapter represents an episode, would that suit you?

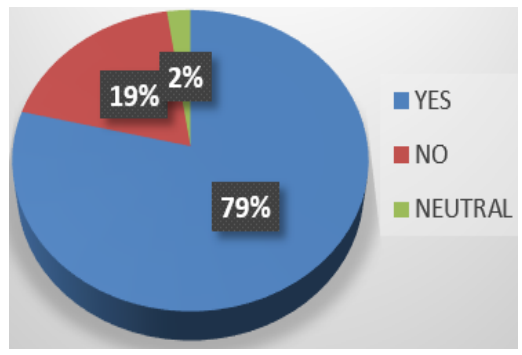

Figure 4. lesson as televisionserie.

\section{Comments on the survey results:}

- 79\% wish to improve their academic skills using ICT tools.

- 79\% wish to have a captivating course in the form of a television series where, for a discipline, an episode constitutes a chapter.

With these statistics of $79 \%$ favorable to a techno-pedagogic approach, the teaching team has developed an adapted tool.

ii) Survey based on the Contextual Immersion Pedagogy approach

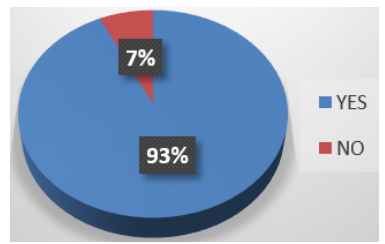

Figure 5 Did you like the video?

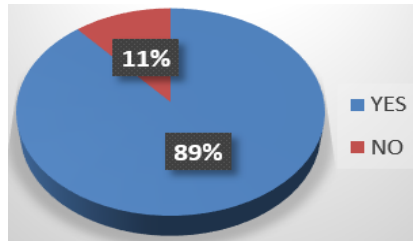

Figure 6 Is it necessary to make similar videos for all the chapters?

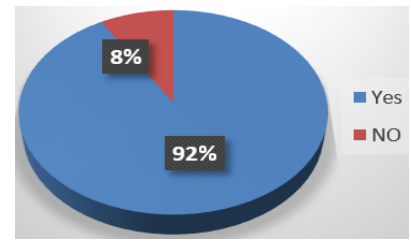

Figure 7 Would you like similar videos in other disciplines? 


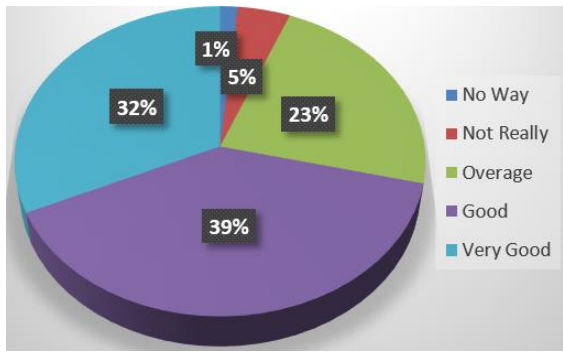

Figure 8 Did this video help you understand the course?

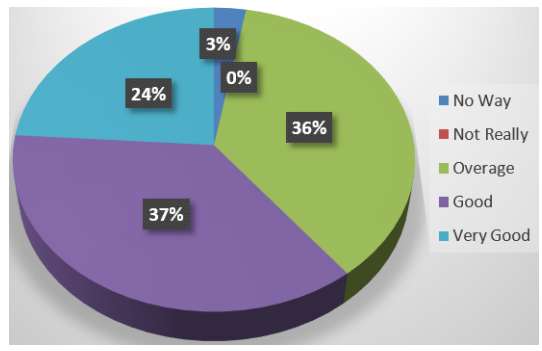

Figure 9 Do you think that this type of videos facilitates the understanding of mathematics chapters?

\section{Comments on the survey results:}

\begin{tabular}{cccccccc}
\hline $\begin{array}{c}\text { Students } \\
\text { who like } \\
\text { the } \\
\text { video }\end{array}$ & $\begin{array}{c}\text { Students } \\
\text { who } \\
\text { would } \\
\text { like to } \\
\text { have } \\
\text { similar } \\
\text { videos for } \\
\text { all } \\
\text { lessons }\end{array}$ & $\begin{array}{c}\text { Students } \\
\text { who would } \\
\text { like to have } \\
\text { similar } \\
\text { videos in } \\
\text { other } \\
\text { disciplines }\end{array}$ & $\begin{array}{c}\text { Students } \\
\text { who did not } \\
\text { understand } \\
\text { anything at } \\
\text { all about the } \\
\text { course using } \\
\text { the video }\end{array}$ & $\begin{array}{c}\text { Students } \\
\text { who did } \\
\text { not really } \\
\text { understand } \\
\text { the course } \\
\text { through } \\
\text { the video }\end{array}$ & $\begin{array}{c}\text { Students } \\
\text { who } \\
\text { averagely } \\
\text { understood } \\
\text { the course } \\
\text { through the } \\
\text { video }\end{array}$ & $\begin{array}{c}\text { Students } \\
\text { who } \\
\text { understood } \\
\text { the course } \\
\text { well } \\
\text { through the } \\
\text { video }\end{array}$ & $\begin{array}{c}\text { Students } \\
\text { who } \\
\text { the course } \\
\text { very well } \\
\text { through the } \\
\text { video }\end{array}$ \\
\hline $92.95 \%$ & $88.73 \%$ & $91.54 \%$ & $1 \%$ & $5 \%$ & $23 \%$ & $32 \%$ & $39 \%$ \\
\hline
\end{tabular}

\section{Discussions}

In a CBA situation for the same course, the learners are bored and more than $60 \%$ are present for fear of disciplinary reprisals. Others ask for endless exit permits to escape the constraint of learning a course with skills that they are supposed to have but that they do not have. With the approach that we proposed above, the results are opposite to those of the CBA because more than $92 \%$ of the class was captivated in front of this video so they recognized themselves as actors in similar situations. However we can also notice that:

- The design time is long compared to other approaches while the learning time is shorter. Then the learner saves the time lost by the designer

- The contextualization through pedagogical differentiation makes the task of the designer more complex but effective. This aspect is not always developed in other approaches (CBA and OBA)

- $\quad$ Production requires additional resources

- $\quad$ Learning, although easy, requires that the learner has ICT tools which are difficult to acquire for certain but essential nowadays 


\section{Conclusion}

The objective of this work was to prove that a new approach based on techno-pedagogy implementing pedagogical differentiation was suitable for learners of a certain age (10 - 18 years old) due to their affinities with ICT gadgets. From the polls of an experiment in the classroom we noticed a particular interest of the learners to follow the course on this new form despite the fact that the subject matter for the lesson is often not affected by these learners. The results are very satisfactory and work continues in this direction to improve this approach which is like a contract between the learner and the teacher. They are given what they like and the educational objectives are attained at the same time.

\section{References}

Avanzini Guy (1986). Différencier la pédagogie, pourquoi ? Comment ? Lyon : Centre régionaldedocumentation pédagogique.

Baluteau François (2014). La différenciation pédagogique : quels modes d'explication sociologique ? Revue française de pédagogie, $\mathrm{n}^{\circ}$ 188, p. 51-62.

Bloom, B.S., et al. (1975). Taxonomie des objectifs pédagogiques, Tome I, Domaine cognitif. Montréal : Centre d'animation, de développement et de recherche en éducation.

Bonner, S. E. (1999). Choosing teaching methods based on learning objectives: An integrative framework.Issues in Accounting Education, 14(1), 11-15.

Bosman, C., Gérard, F. \&Roegiers, X., 2000. Quel Avenir Pour Les Compétences ? 1er éd., Bruxelles: De Boeck Université.

Boutin, G. \& Julien, L., 2000. L'obsession des compétences. Son impact sur l'école et la formation des enseignants. Editions Nouvelles., Montréal.

Burke, J.W., 1989. Competency Based Education and Training, Routledge.

Burns, R.W. \&Klingstedt, J.L., 1973. Competency-based education, Educational Technology Publications.

Burns Robert (1971). Methods for individualizing instruction. EducationalTechnology, $\mathrm{n}^{\circ}$ 11, p. 55-56.

Carretteet Rey, 2010 lifelong learning skill

Cèbe Set al. (2015). Quelles pratiques d'enseignement pour les élèves en difficulté d'apprentissage? In GaëtaneChapelle\& Marcel Crahay (dir.),

De Landsheere, V., et de Landsheere, G.(1989). Définir les objectifs de l'éducation. (6e éd.). Paris : Pressesuniversitaires de France.

Fontaine, F.(1989). Les objectifs d'apprentissage. (3e éd.). Montréal : Service pédagogique, Université de Montréal.

Nguyen D.Q et J.G. Blais, (2007). Approche par objectifs ou approche par compétences ? Repères conceptuels et implications pour les activités d'enseignement, d'apprentissage et d'évaluation au cours de la formation clinique

Roegiers, X. (2001). Une pédagogie de l'intégration, Compétences et intégration des acquis dans l'enseignement. Bruxelles : De Boeck. 